\title{
THE STUDY OF BACTERIA-DESTRUCTORS OF ORGANIC POLLUTION FROM COLLECTION OF MICROORGANISMS
}

\author{
Kurmanbayev A.A, Baigonussova Zh. A. \\ National Center for Biotechnology \\ Korgalzhyn highway, 13/5, Astana, Kazakhstan \\ zhanatb71@mail.ru
}

\begin{abstract}
To replenish the collection of microorganisms 125 strains of oil-decomposing bacteria were isolated. 34 bacterial isolates were isolated from enrichment cultures, consuming sodium dodecyl sulfate as the only carbon source. As a result, it was found that the most active were 20 isolates. 65 isolates of microorganisms were isolated from the reservoir waters of Western Kazakhstan, oil sludge and waste waters by the method of enrichment cultures. The most active were 47 isolates. It was found that the ability to dispose of oil was greatest in the isolate, which disposed of oil by $73 \% .26$ isolates capable of decomposing fat were isolated from wastewater in Astana. 16 Isolates revealed the highest lipase activity. strains.

Key words: isolates, bacterial strain, destructor of surfactant, industrial-value
\end{abstract}

\section{INTRODUCTION}

Soil and subsoil horizons that are contaminated with organic xenobiotics (the use of pesticides, the creation of surface storage tanks and the burial of industrial and household waste, sewage sludge) experience a great burden as a result of anthropogenic activity. There is a high risk of pollution of groundwater, the self-purification of which is much slower than surface. The situation is aggravated by the fact that synthetic substances that do not exist in nature and are not degraded in the environment enter the environment, many of which have negative biological (including carcinogenic) activity. They accumulate in the components of the ecosystem.

In solving environmental problems, the potential of biotechnology increase. By now, a new direction has formed - environmental biotechnology as a specific use of biotechnology in solving environmental issues.

Microbial culture collections are fundamental to biotechnology. Cultures stored in collections are the basis for using the achievements of microbiology, genetics, and molecular biology in industry, agriculture and medicine. The collection of cultures of microorganisms also contains the necessary information of the origin and properties of the stored strains. The availability of such data contributes to increasing the efficiency of biotechnological research, reducing the cost of organizing industrial production.

Microorganisms are ubiquitous in the environment, playing an important role in biogeochemical cycles. Their ability to absorb xenobiotic compounds in recent years has received great attention due to their persistence and toxicity. Therefore, the microbial degradation of xenobiotics known as bioremediation becomes an urgent task in connection with the development of cost-effective and environmentally friendly technologies for the purification of natural environments [1].

Microorganisms can destroy a wide range of organic pollutants. However, the biodegradation process is usually very slow and, therefore, this process can be accelerated by increasing the number of active cultures of destructive microorganisms available in collections of microorganisms. An example of such collection is the regional profiled collection of 
alkanotrophic microorganisms of the Institute of Ecology and Genetics of Microorganisms of the Ural Branch of the Russian Academy of Sciences http://www.iegm.ru/iegmcol/.

The use of microbial preparations in environmental protection is a relevant problem of the Republic of Kazakhstan, because significant areas of Kazakhstan are vulnerable to pollution by xenobiotics, primarily oil and oil products, surfactants and other organic substances. In this regard, it is extremely important to have a collection of bacteria-destructors of organic compounds and xenobiotics.

The aim of the research was to create and replenish the collection of microorganisms with strains of bacteria-destructors of organic substances.

\section{Materials and methods}

The sources for isolation of bacteria: oil from the «Zhaiykmunay gas» field, the formation water of the «Morskoye» field, well № 10; the formation water of the «KarazhanbasKakimzhan» field; the formation water of the «Uzen - reservoir water» field; the formation water of the «X-Morskoye Atyrau» field, well № 47; crude oil of the "X - Morskoye" field, well № 47; oil sludge of the «Morskoye field», well № 12 .

The following media were used to accumulate, isolate, and determine the number of strains of destructors: meat - peptone agar; Luria-Bertani, mineral medium M9, E8 [2].

For screening surfactant-degrading strains, the Hansen color reaction method on dies was used as a test [3]. For screening, standard SDS solutions were prepared in the following concentrations: $100 \mu \mathrm{l} / 100 \mathrm{ml} ; 500 \mu \mathrm{l} / 100 \mathrm{ml} ; 1000 \mu \mathrm{l} / 100 \mathrm{ml} ; 5000 \mu \mathrm{l} / 100 \mathrm{ml}$, dichlorophenolindophenol solution - $2 \mathrm{mg} / \mathrm{ml}$, bacterial suspension - $10^{7} \mathrm{CFU} / \mathrm{ml}$. A suspension of $200 \mu \mathrm{l}$ of bacterial cells was placed in the wells of the plate, $10 \mu \mathrm{l}$ of SDS and 400 $\mu \mathrm{l}$ of dichlorophenolindophenol were added to this well, the plate was covered. After that tablet was placed in a thermostat at $28^{\circ} \mathrm{C}$ for 18 days. The results are taken into account within $3,6,9$, 12 days.

To identify microorganisms that destroy anionic surfactants, a TTX test was used. Into the prepared solid medium containing mineral salts (E8 medium with $1 \%$ of TTX) and $0.1 \%$ of anionic surfactant as the sole source of carbon and energy, cultures of the tested microorganisms were seeded with an injection. Inoculated plates are incubated at $30^{\circ} \mathrm{C}$ for 3 days. Then they are poured with a $1.0 \%$ of aqueous solution of 2,3,5-triphenyltetrazolium chloride. As a result, the surface of the solid medium is painted milky white with light transparent zones around the colonies of microorganisms that destroy stearox -6 .

The quantitative content of surfactants was determined by the accelerated method of Mozhaev E.A. [4].

The study of the oil-oxidizing activity of hydrocarbon-oxidizing microorganisms was carried out in $750 \mathrm{ml}$ Erlenmeyer flasks containing $100 \mathrm{ml}$ of Voroshilova-Dianova (VD) medium [2]. 1\% of oil from the "ZhayykMunaigas" oil and gas field of the Atyrau region with a density of 0.84 was added in medium. The cultivation of microorganisms was carried out in flasks containing $100 \mathrm{ml}$ of culture medium on a shaker at $160 \mathrm{rpm}$ and a temperature of $25^{\circ} \mathrm{C}$ for 14 days. Nutrient medium was inoculated with a suspension of 2-day-old cultures of microorganisms. Qualitative changes in growth were evaluated by a change in the color of the oil, by the degree and nature of the destruction of the oil film and the turbidity of the medium. Growth rate was evaluated on a five-point scale.

Determination of oil content in samples by gravimetric method.

Residual oil and oil products from the culture fluid were extracted with chloroform $(50 \mathrm{ml}$ of medium: $15 \mathrm{ml}$ of chloroform) in a separatory funnel. Chloroform was added portionwise, rinsing the flask. The extract was evaporated for 3 hours on a rotary evaporator. The resulting sample was weighed on an electronic weighing scale. The amount of consumed oil was calculated by the formula (1):

$$
\mathrm{A}=\frac{(\mathrm{a} 1-\mathrm{a} 2)}{\mathrm{a} 1} \times 100 \%
$$


A - the amount of consumed oil, \%, "a1" - the amount of supplied oil, g; "a2" - the amount of residual oil, g [6].

For the qualitative determination of lipolytic microorganisms, sterile molten beef tallow is poured into Petri dishes and drained immediately. In the same Petri dish, $1 \mathrm{ml}$ of the studied dilution of the product is introduced and poured with molten nutrient agar. The seeded dishes are kept for 5-6 days at room temperature $\left(20-23{ }^{\circ} \mathrm{C}\right)$. White zones form around colonies of lipolytic bacteria [7].

The process of biodegradation of plant and animal fats by the studied microorganisms was carried out on the mineral medium M9. Fats and oils were added in an amount of $1 \%$ of weight. Microorganisms were cultured in Erlenmeyer flasks with a volume of $250 \mathrm{ml}$ on a shaker at a temperature of $28-30{ }^{\circ} \mathrm{C}$, with a rotation speed of $180 \mathrm{rpm}$ for $16-96$ hours. The inoculum was introduced as a 1-day-old culture of microorganisms with a cell content of $10^{9} \mathrm{CFU} / \mathrm{ml}$. The residual fat content was determined by the gravimetric method after extraction with hexane [8].

A method for quantifying the lipolytic activity of the studied strains. In order to determine lipolytic activity, the method of alkalimetric titration of free fatty acids was used. A suspension of 1-day-old culture of microorganisms (citrate-phosphate buffer) in an amount of $10^{9} \mathrm{CFU} / \mathrm{ml}$ was seeded in a prepared sterile emulsion of fat $(0.5 \%$ of fat or oil, $0.25 \%$ of Tween as emulsifier) in flasks. Emulsions seeded with microorganisms were incubated in a thermo-shaker at $28-30{ }^{\circ} \mathrm{C}$. Samples of the culture fluid for titration were taken. The samples were titrated with a $0.5 \mathrm{~N}$ potassium hydroxide solution in the presence of bromothymol blue until the color changed from yellow to blue. The activity of lipase (X) was expressed by the number of milliliters of an alkali solution consumed to neutralize free fatty acids formed during hydrolytic decomposition of $1 \mathrm{~g}$ of oil (fat) and was calculated by the formula (2):

$$
X=\frac{(a-b)}{H}
$$

$\mathrm{a}$ - the amount of potassium hydroxide solution spent on the titration of the test sample, $\mathrm{ml} ; \mathrm{b}$ - the amount of potassium hydroxide solution spent on the titration of the control sample, $\mathrm{ml} ; \mathrm{n}$ - a hinge of oil (fat), g [9].

\section{RESULTS AND DISCUSSION}

Isolation of bacteria strains destroying surfactants from wastewater and the study of destruction activity. Bacterial strains that can destroy surfactants were isolated from wastewater, and the destruction activity of the isolated colonies was studied. Bacteria were isolated from the drainage wells of the private sector, car washes, the canteen of Nur-Sultan and from the soil of the Mangystau region (Figure 1).

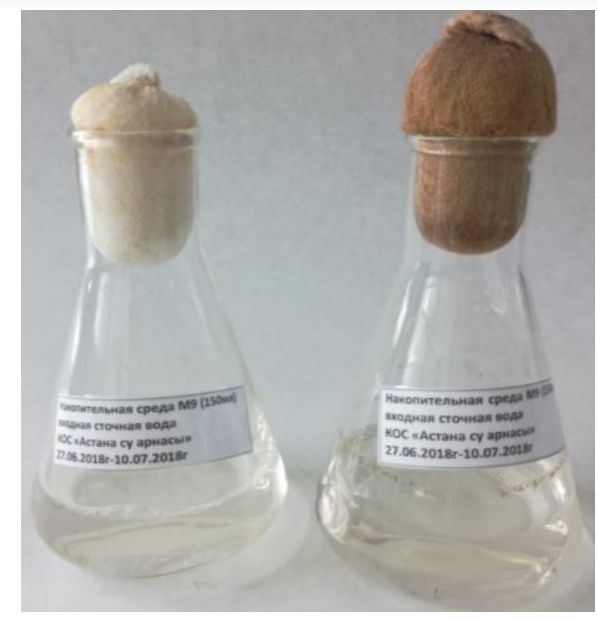

A

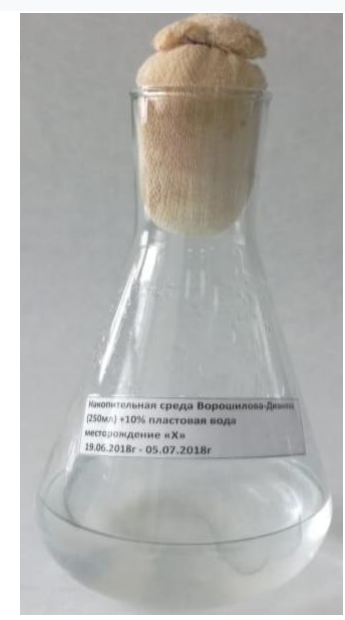

B 
A - surfactant-degrading microorganisms on the medium M9, B - surfactant-degrading microorganisms on the medium VD

Fig. 1. Cumulative cultures of surfactant destructive microorganisms on the 14th day

The 34 bacterial strains capable of growing on the M9 mineral medium with the addition of SDS as the sole carbon source were isolated from accumulative cultures. As a result of the initial screening of surfactant-degrading microorganisms (SDS), a positive result was found in 10 bacterial strains. The most active isolates: Sd 6, Sd 30, LB KOC 1, KOS 2, LB KOC 9, which destroyed SDS in doses from 100 to $5000 \mathrm{mg} / 1$ in 12 days; Sd 6 strain turned out to be less active among the studied bacterial strains (Figure 2).

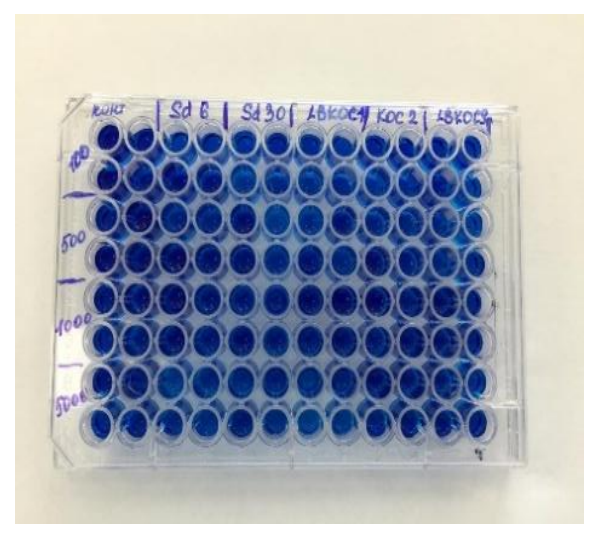

A

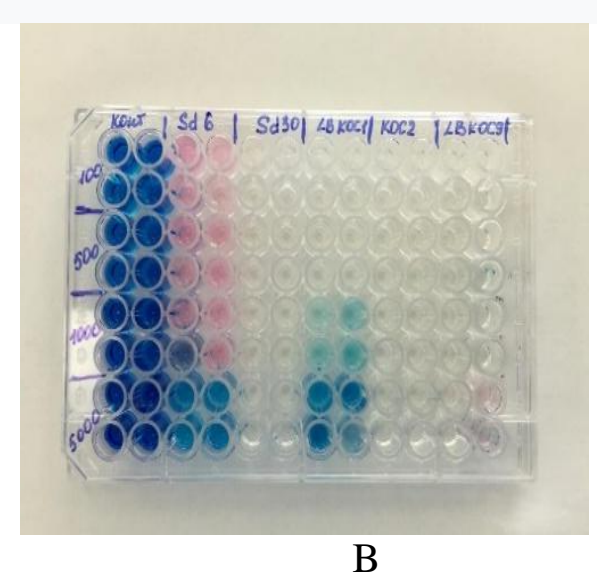

B

A - reaction with SDS dye for 1 day at concentrations of 100-5000 mg / 1;

B - change over 12 days in a series of concentrations 100-5000 mg / 1

Fig. 2. Color test with dye for rapid testing of the destructive activity of bacterial strains

To screen the ability of microorganisms to utilize synthetic surfactants, a qualitative biochemical test with $1 \%$ solution of the colorless salt of 2,3,5-triphenyl-tetrazolium chloride (TTX) was carried out. For this procedure, culture was grown on solid mineral medium M9 with the addition of surfactants (SDS) and 1\% TTX solution. When microorganisms utilized SDS, TTX was restored to triphenyl formazan (TFP), while the cultures and zones around the colonies were stained red. The method is based on the restoration of the dye and its discoloration when carbon is consumed by microorganism strains.

Bacterial strains were incubated at $28^{\circ} \mathrm{C}$. After 3, 6, 9, 12 and 15 days, the staining zones of the colonies of the studied microorganism were counted. The stained area on the Petri dishes appeared on the third day and gradually increased for nine and fifteen days. Among the 34 isolated bacterial strains, the most active were $\mathrm{Sd} 26, \mathrm{Sd} 27, \mathrm{Sd} 16, \mathrm{Sd} 17, \mathrm{Sd} 25, \mathrm{Sd} 23, \mathrm{Sd} 2$.

A quantitative assessment of SDS destruction for the isolated bacterial strains was carried out at concentrations of $10.0 \mathrm{mg} / \mathrm{L}$. It was established that 20 strains: KOC 2, KOC 3, KOC 4, LBKOC 5, Sd 23, Sd 2, Sd 28, Sd 27, Sd 17, Sd 26, Sd 20, Sd 9, Sd 27, Sd 17, SD 11, Sd 12, Sd 3, LBKOC 3, LBKOC 9, LBKOC 7 were the most active. The concentration of residual SDS varied from $0.13-0.39 \mathrm{mg} / 1$ (Figure 3,4 ). 


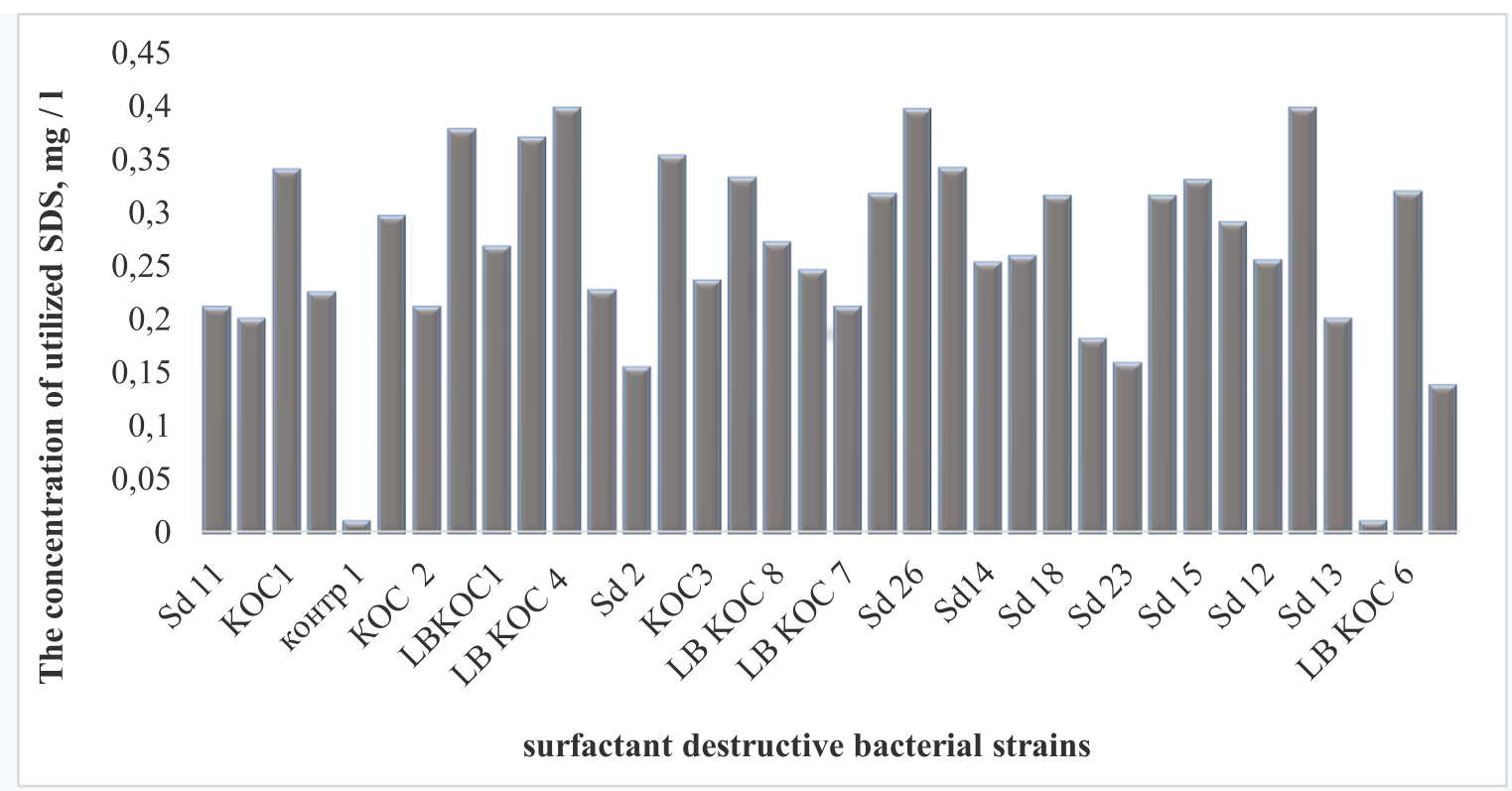

Fig.3. Results of SDS concentration after exposure to surfactant destructive bacteria

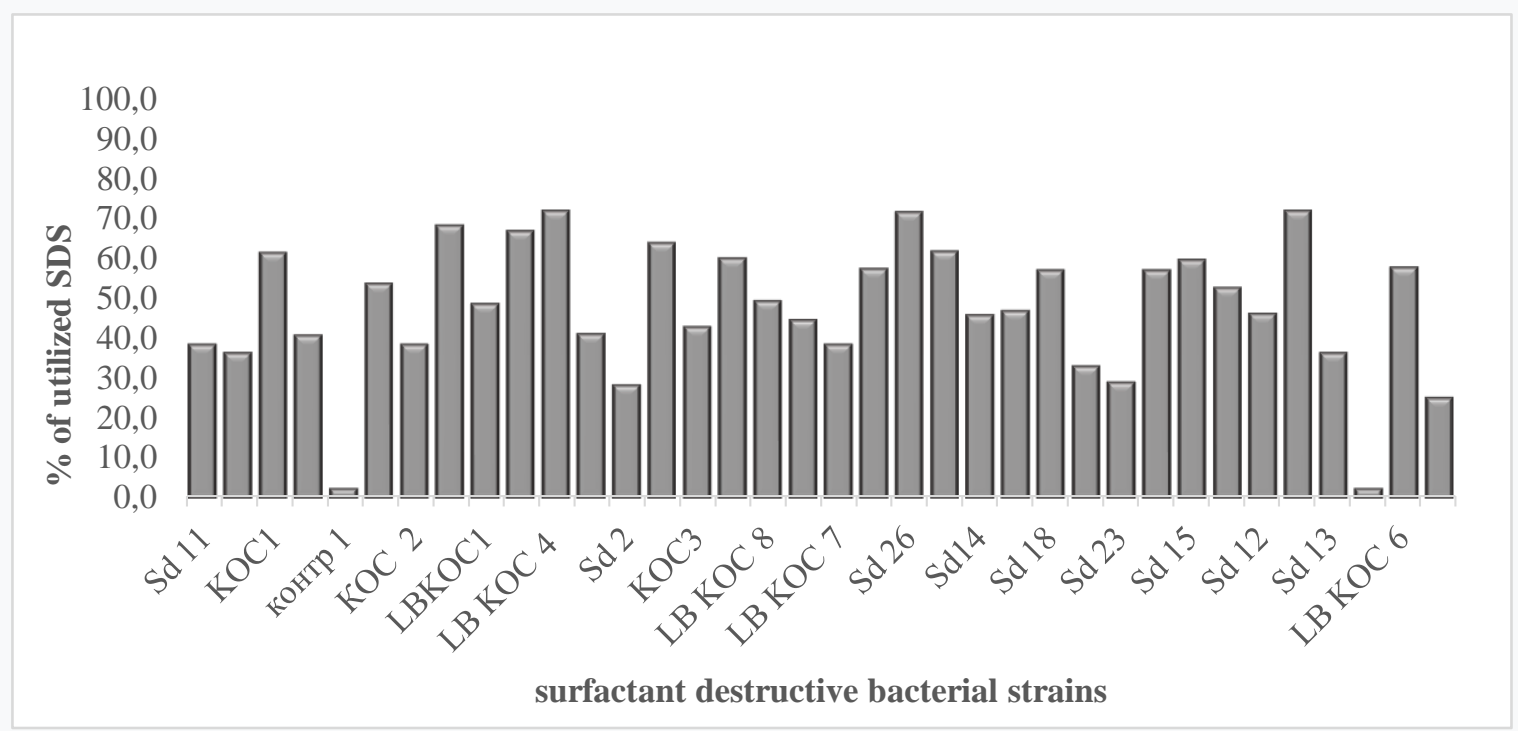

Fig. 4. The percentage of SDS after exposure to surfactants destructive bacteria

Thus, it was found that the selected surfactant destroying microorganisms are able to destroy SDS from $25 \%$ to $73 \%$.

Isolation of bacteria that destroy oil from wastewater and oil-contaminated soils, and study of oil-oxidizing activity. The 65 strains of bacteria were isolated from the formation water of the «Morskoye» field, well № 10; the formation water of the «Karazhanbas-Kakimzhan» field; the formation water of the «Uzen - reservoir water» field; the formation water of the «XMorskoye Atyrau» field, well № 47; crude oil of the "X - Morskoye" field, well № 47; oil sludge of the «Morskoye field», well № 12; and from wastewater of the Astana Su Arnasy state-owned enterprise. Oil-oxidizing activity and the cultural properties of the isolated colonies were studied. Oil-oxidizing bacteria were isolated from accumulative cultures (Figs. 5, 6). 


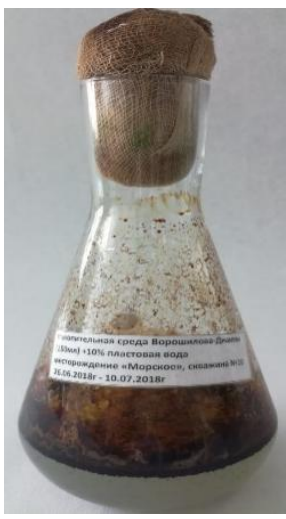

A

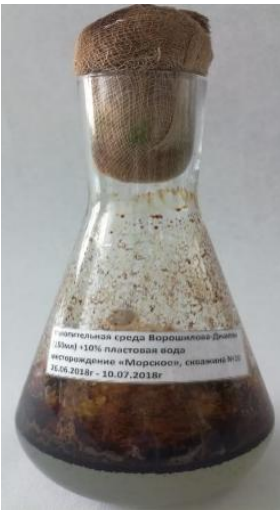

B

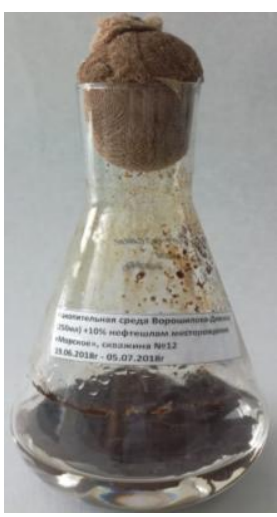

$\mathrm{C}$

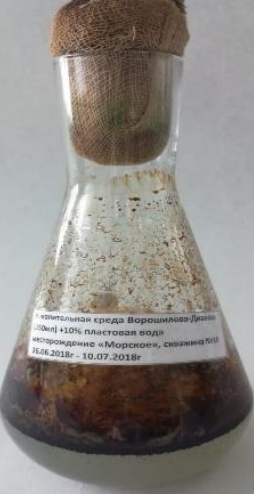

D

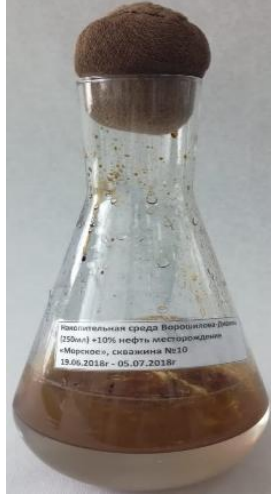

$\mathrm{E}$

A - formation water of the «Morskoye» field, well № 10; B - formation water of the Karazhanbas-Kakimzhan field; C - oil sludge of the «Morskoye field», well № 12; D - formation water of the "Uzen - reservoir water" field;

E- crude oil of the "X - Morskoye" field, well № 47

Fig. 5. Cumulative cultures of oil-oxidizing microorganisms

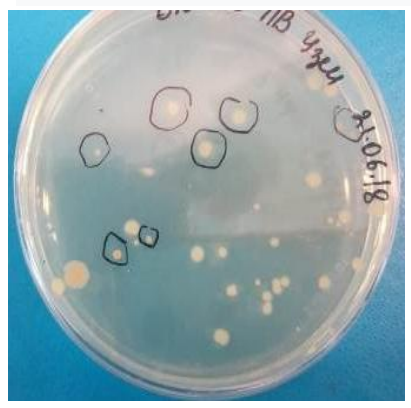

A

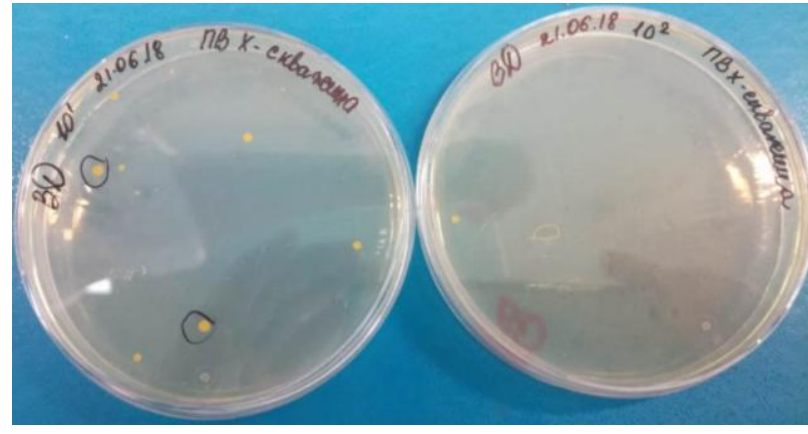

$\mathrm{C}$

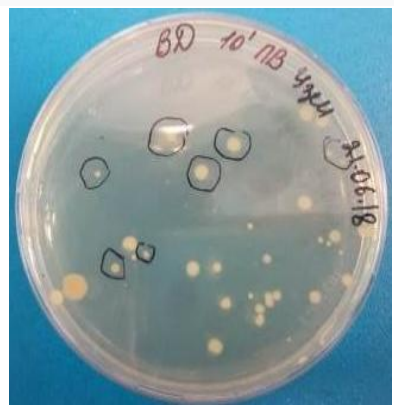

$.06 .1810^{2}$

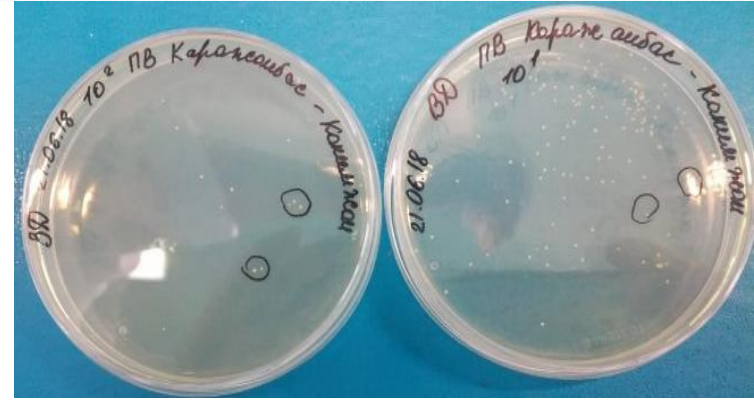

B

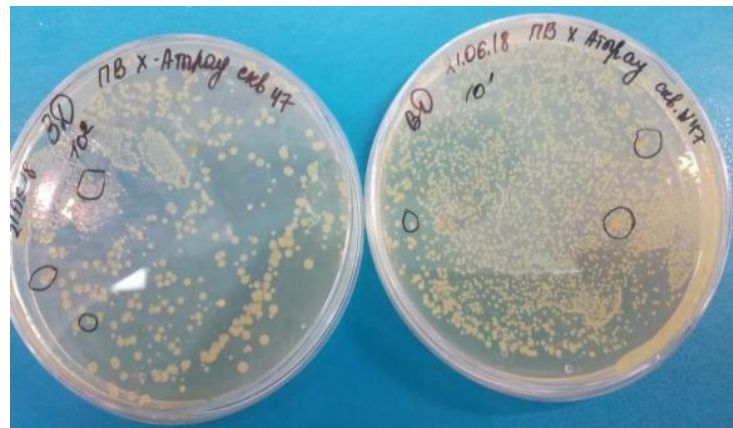

Д

A - solid medium VD formation water field "Uzen" - reservoir water "; B - solid medium; VD layer water; Karazhanbas-Kakimzhan deposit; C - solid medium VD oil sludge field "Offshore" well No. 12; D - solid medium VD crude oil field "X - Marine" field No. 47

Fig. 6. Growth of oil-oxidizing strains from a storage medium on a solid medium VD

New isolated strains of bacteria capable of utilizing oil from the fields of Atyrau region were screened. When growing oil-oxidizing cultures on the VD mineral medium with oil, it was found that the strains Od 1, Od 2, Od 4, Od 9, Od 11, Od 13, Od 16, Od 19, Od 24, Od 29, Od 28 were the most active among the studied cultures. (Figures 7, 8). 


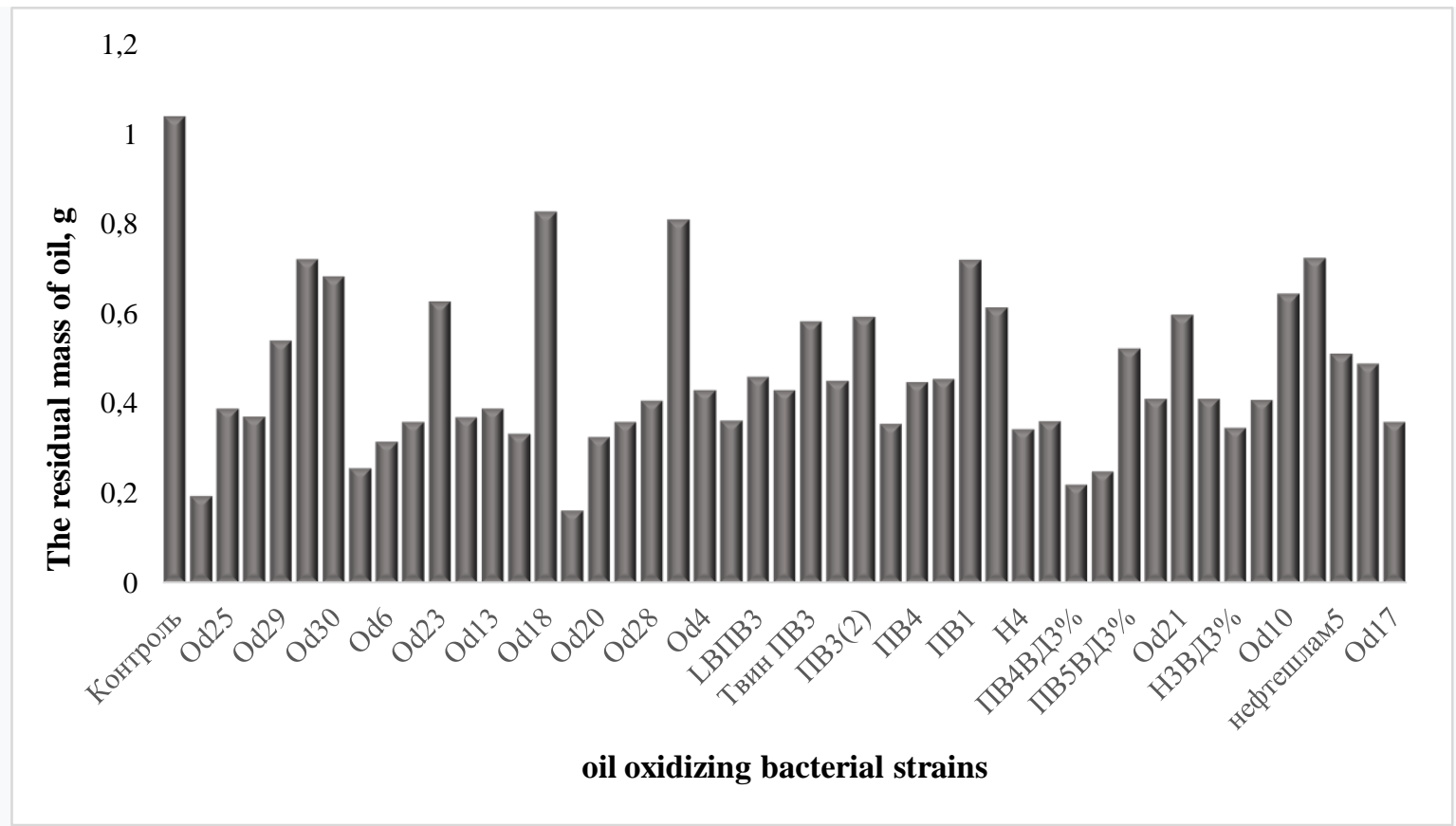

Fig. 7. Results of oil consumption by isolated oil-oxidizing bacteria

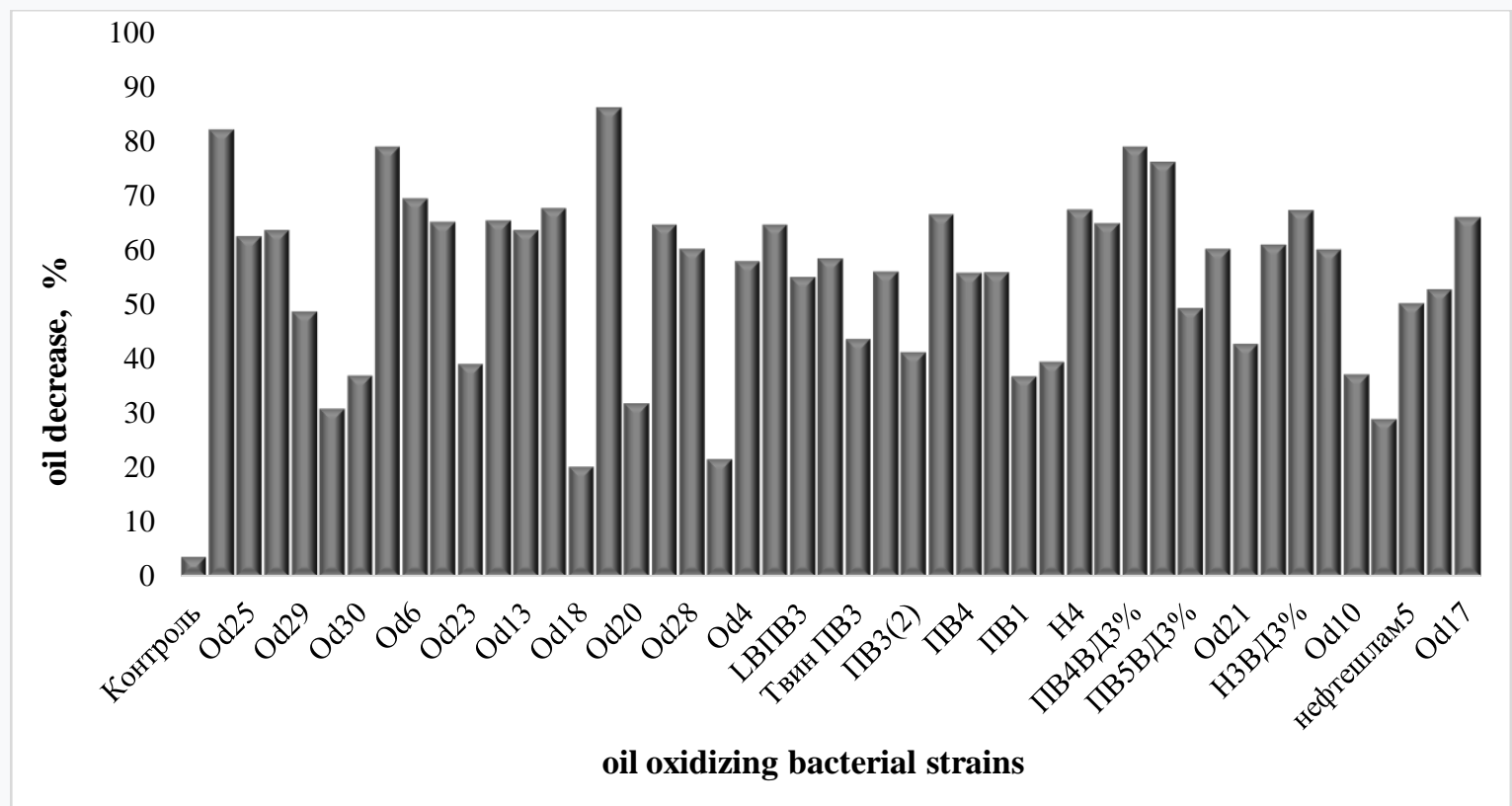

Fig. 8. Results of oil consumption by isolated oil-oxidizing bacteria

Isolated cultures were grown on slant nutrient agar. Inoculation of a liquid nutrient medium was carried out using the mentioned initial cultures of microorganisms - flushing from slant nutrient agar $(\mathrm{n} \times 108 \mathrm{CFU} / \mathrm{ml})$ in an amount of $1 \%$. Cultivation was carried out for 48 and 72 hours on a shaker at a $28{ }^{\circ} \mathrm{C}$. Determination of viable bacterial cells was carried out by plating from the appropriate dilution of the culture in Petri dishes with a solid nutrient medium.

The oil-oxidizing activity of bacteria was established by the gravimetric method for their assimilation of oil in a liquid nutrient medium containing $1 \%$ of crude oil, after cultivation on a shaker for 14 days.

The most active were the strains Od 1, Od 3, Od 7, Od 11, Od 18 Od 13, PV4VD3\%, N4VD 3\%. While studying the oil-oxidizing activity in cultures, it was found that the ability to utilize oil was highest in the strain Od 1, which utilized oil by $73 \%$ and in strain Od 3- by $59 \%$, by $54 \%$ - in strains Od 7, Od 11.

It was established that 47 bacterial strains are the most active, the degree of oil utilization in which ranged from $81 \%$ to $20 \%$, the degree of utilization in the control variant was $3 \%$. 


\section{Isolation of bacteria that destroy fat from wastewater and industrial facilities, and the study of fat- degrading activity}

Isolates that destroy fats were isolated from wastewater and industrial facilities and their fat- degrading activity was studied (Figure 9).

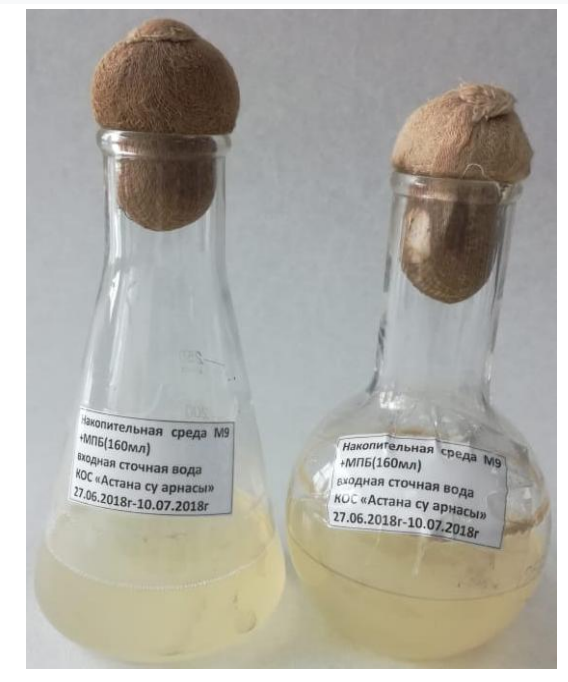

A

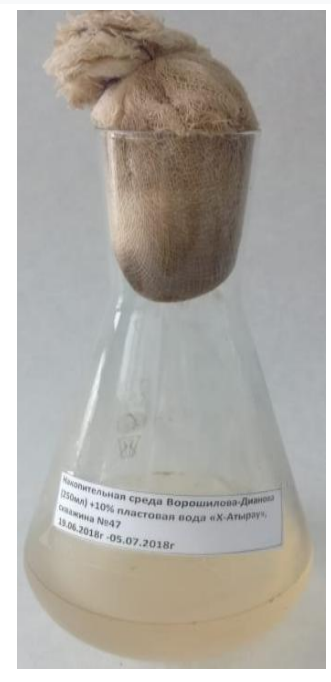

Б
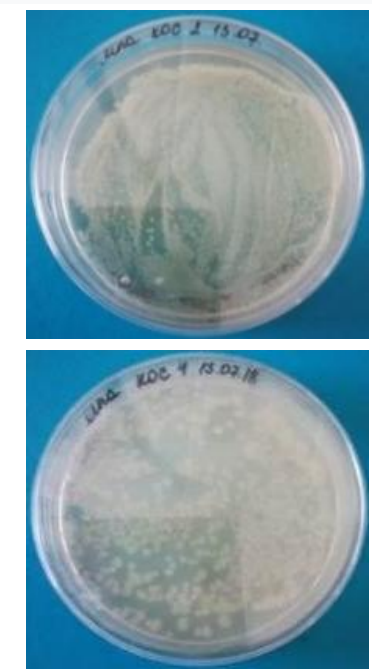

$\mathrm{C}$

A - on M9 medium with fat-degrading microorganisms; B - on VD medium with fat-degrading microorganisms; $\mathrm{C}$ - on solid nutrient medium

Fig. 9. Cumulative culture of fat-degrading microorganisms

26 bacteria strains were isolated from Astana wastewater. When determining the lipolytic activity of bacteria, a qualitative method with beef fat was used. As a result, 16 active strains of bacteria were detected: Fd 1, Fd 3, Fd 12, Fd 13, Fd 9, Fd 15, Fd 16, Fd 24, Fd 27, Fd 22, Fd 19 Fd 25, Fd 2, Fd 13, K-1, Fd 23 (Figure 10).

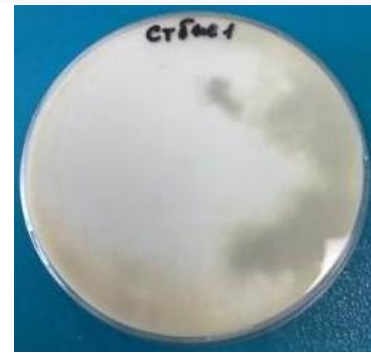

A

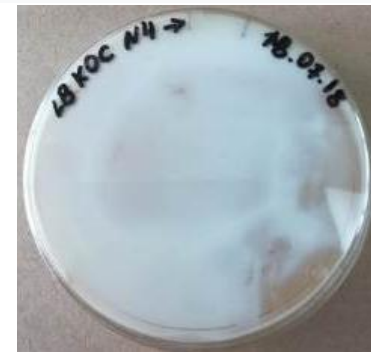

Б

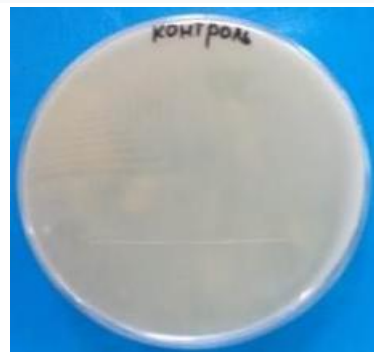

C

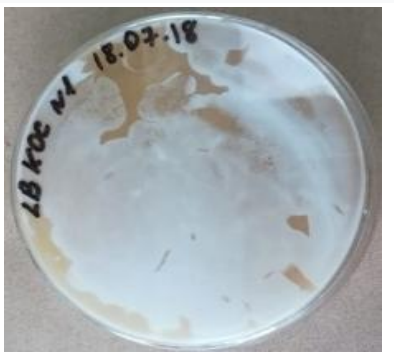

Д

A - strain Stbj (Fd 1) on a solid nutrient medium with beef fat and soy flour; B - strain Stbj (Fd 1) on solid nutrient medium LB with beef fat and soy flour; C - control - strain Stbj (Fd 1) on a solid nutrient medium with beef fat without soy flour; D - strain LBKOC 1 on solid nutrient medium LB with beef fat and soy flour

Fig. 10. Growth of fat-degrading bacteria strains from the storage medium on solid media

After exposure, white zones form around colonies of lipolytic bacteria. A quantitative assessment of the lipolytic activity of bacteria in relation to sunflower oil was made (Figure 11). 


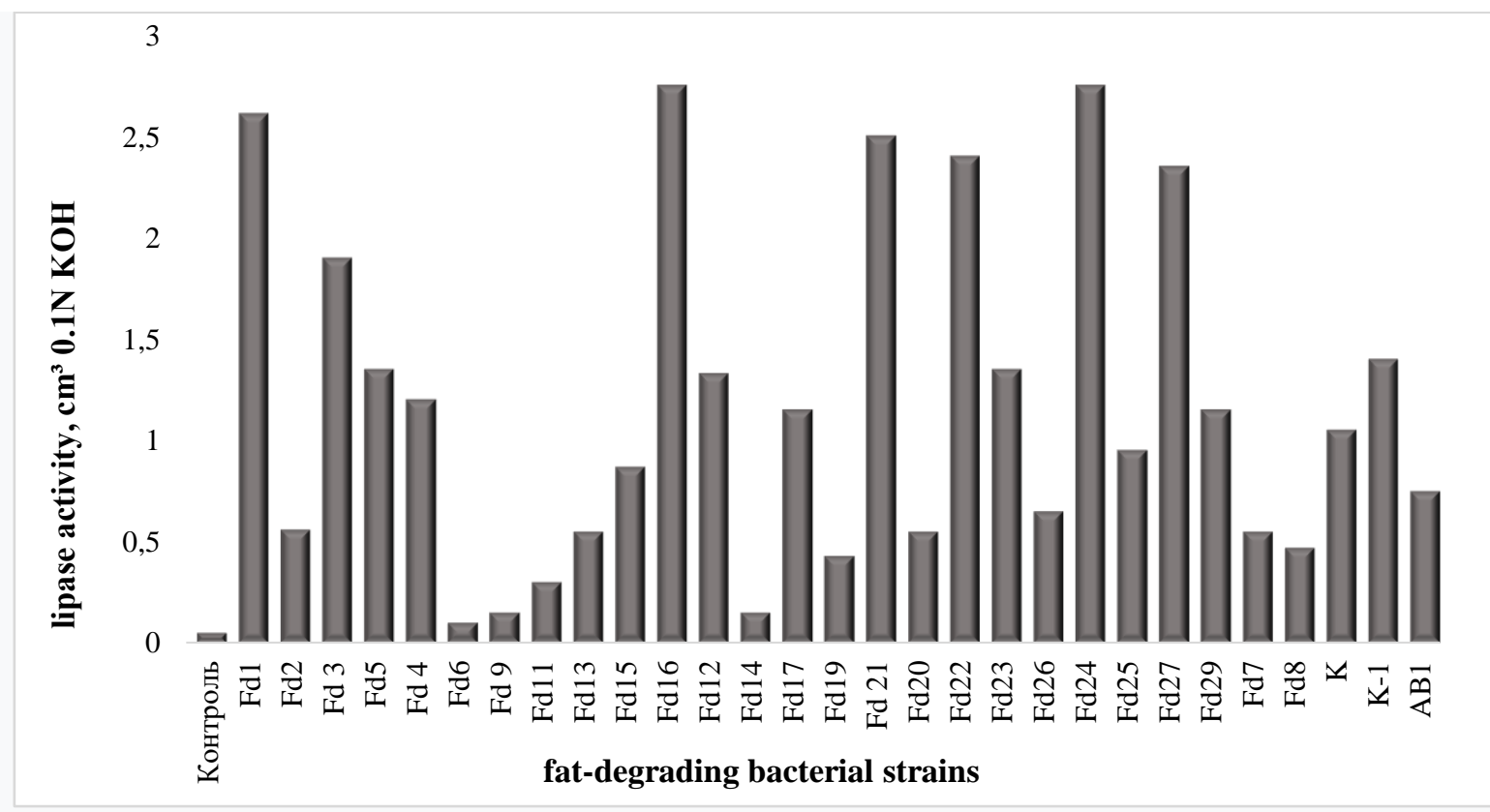

Fig. 11. Results of a quantitative assessment of the lipolytic activity of the isolated fat-degrading bacteria strains

Thus, the study of the destructive activity of the newly isolated strains makes it possible to replenish the collections with active strains of bacteria- degrading of organic substances.

\section{CONCLUSION}

Studies of the degradation of xenobiotics by bacteria allow us to detect active strains of destructors and select the most promising ones for bioremediation of polluted environments. This method is environmentally friendly, highly economical and efficient in comparison with other methods.

In the course of study of organic matter destructors, a working collection of 125 bacterial strains was obtained, in which 83 bacterial strains were promising in activity. Oil oxidizing activity of the strains ranged from 20 to $81 \%$ after 14 days in a medium with oil, bacteria decomposed surfactants in the medium by $71-76 \%$. Active fat-degrading strains showed lipase activity above $2.4 \mathrm{ml}$ of $0.1 \mathrm{n} \mathrm{KOH}$ per $1 \mathrm{~g}$ of substrate.

\section{Acknowledgements}

This work was supported by the Ministry of Education and Science of the Republic of Kazakhstan (STP BR05236334 "Creation of a biobank of microorganisms, cell cultures, genomic and genetic engineering materials to preserve biodiversity and provide a resource base for biotechnology" for 2018-2020)

\section{REFERENCES}

1. Singh S.N. Microbial degradation of xenobiotics [Microbial degradation of xenobiotics]. Berlin, Springer-Verlag Berlin Heidelberg, 2012. - 483 p.

2. Egorov N.S. Practicum Microbiology [Workshop on Microbiology]. Moscow, Moscow University Publ., 1983. 198 p.

3. Hanson K.G., Desai J.D., Desai A.J. A rapid and simple screening technique for potential crude oil degrading microorganisms. Biotechnology Techniques, 1993, vol. 7, no. 2, pp.745-748.

4. Mozhaev E.A. Zagreznenie vodoemov poverhnostno-aktivnimi veshestvami [Water pollution by surface-active substances]. Moscow, Medicine, 1976. 96p. 
5. Lurie Y. Yu. Analyticheskaia hemia proizvodstvenno stochnich vod [Analytical chemistry of industrial wastewater]. Moscow, Chemistry, 1984. 448 p.

6. Bannikova L.A. [Microbiological basis of dairy production]. Moscow, Agropromizdat, 1987. $400 \mathrm{p}$.

7. Tabesh, M., Feizee Masooleh, M., Roghani, B. et al. Life-Cycle Assessment (LCA) of Wastewater Treatment Plants: A Case Study of Tehran, Iran. Int J Civ Eng 17, - 2019. P.11551169.

8. Kolotova O.V., Sokolova I.V. The study of the lipolytic activity of bacteria isolated from the effluent of a meat factory. Age of Science, 2017, no. 9, pp.228-232.

\title{
ОРГАНИКАЛЫҚ ЗАТТАРДЫ ЫДЫРАТҚЫШ БАКТЕРИЯЛАРДЫН КОЛЛЕКЦИЯСЫН ЖАСАУ ЖӘНЕ ОЛАРДЫН КАТАРЫН ТОЛЫКТЫРУ ҮШІН ҚАЗАҚСТАНДА ЛАСТАНҒАН ТОПЫРАҚТАН ЖӘНЕ АҒЫНДЫ СУЛАРДАН БАКТЕРИЯЛЫК ШТАММДАРДЫ БӨЛІНІП АЛУ
}

\author{
Кұрманбаев А.А., Байгонусова Ж.А. \\ Ұлттық биотехнология орталывы \\ Қоргалжын тас жоль, 13/5, Нұр-Сұлтан құаласы, \\ Қазақ̆стан Республикасы \\ zhanatb71@mail.ru
}

\section{ТYЙІН}

Органикалық заттарды ыдыратқыш бактериялардың штаммының коллекциясын толықтыру үшін мұнайды, ББ3-ды және майды ыдыратқыш 125 бактериялардың штаммдары бөлініп алынған. Жинақтаушы қоректік ортадан 34 микроорганизмдердің изоляттары бөлініп алынды, олардың арасынан 20 изоляты белсенді болып шықты. Сонымен ББЗ ыдыратқыш бактериялардың изоляттары ДСН - ды 25\% дан 73\% ға дейін ыдыратқандығы корсетілген. Батыс Қазақстан аймағындағы мұнайлы қойнауқат суларынан, мұнай шламдардан және ағызынды сулардан жинақтаушы қоректік ортаданың көмегімен микроорганизмдердің 65 изоляты бөлініп алынды, олардың 47 белсенді. Зерттелген изоляттарда мұнайды 73\% дейін мұнайды ыдырату қабілеті анықталған. Астана қаласының ағызынды суларынан 26 май ыдыратқыш изоляттар бөлініп алынған. олардың арасынан 16 белсенді изоляттар іріктелініп алынған.

Негізгі сөздер: изоляттар, бактериялды штамм, ББ3 ыдырытқыш, өндірістік кұнды штаммдар.

\section{ИЗУЧЕНИЕ БАКТЕРИЙ-ДЕСТРУКТОРОВ ОРГАНИЧЕСКИХ ЗАГРЯЗНЕНИЙ ИЗ КОЛЛЕКЦИИ МИКРООРГАНИЗМОВ}

Курманбаев А.А., Байгонусова Ж.А.

Национальный цеентр биотехнологии

Кургальжинское шоссе, 13/5,

010000, Республика Казахстан.

zhanatb71@mail.ru

\section{АБСТРАКТ}


Для пополнения коллекции микроорганизмов деструкторов органических загрязнителей были выделены 125 штаммов бактерий, разрушающих нефть, ПАВ и жиры. Из накопительных культур было выделено 34 изолята бактерий, потребляющих додецилсульфат натрия в качестве единственного источника углерода. В результате было обнаружено, что наиболее активными оказались 20 изолятов. Из пластовых вод Западного Казахстана, нефтешламов и сточных вод было выделено 65 изолятов микроорганизмов методом накопительных культур. Наиболее активными оказались 47 изолятов. Было установлено, что способность утилизировать нефть была наибольшей у изолята, который утилизировал нефть на 73\%. Из сточных вод г. Астаны выделено 26 изолятов, способных разлагать жир. Наибольшую липазную активность показали 16 изолятов.

Ключевые слова: изоляты, бактериальный штамм, деструктор поверхностноактивных веществ, производственно-ценный штамм. 